\section{On the bright side}

Steven Rose

Biology and Freedom: An Essay on the Implications of Human Ethology. By S.A. Barnett. Cambridge University Press: 1989. Pp. 376. £32.50, \$39.50.

I'M LEERY about books with the words 'biology and . . .' in the title - they tend to contain yet more angels-on-a-pin discussions by philosophers about the ethical implications of science-fiction genetics, or sociologically naive speculations by biologists about the inevitability of war, the nuclear family and capitalism. Biology and Freedom comes as a refreshing contrast. Professor Barnett is a distinguished ethologist of the school which pre-dates the present-day obsessions with optimal foraging strategies, cost-benefit analyses and genetic fitness calculations, and his previous books include an authoritative study on the social behaviour of the rat. As anyone who has had the good fortune to hear one of his forceful contributions to that great Australian radio institution, The Science Show, will know, he does not suffer fools lightly. But his new book goes beyond the mere debunking of certain currently popular biologistic follies, to offer instead a vision of a humanity set free by our very biological constitution.

Barnett's intentions are perfectly revealed in the epigram from Shaw with which the book opens: "Is human nature incurably depraved? If it is, reading this book will be a waste of time". The first two-thirds of the subsequent text is devoted to a critique of those claims for such incurable depravity that have found their way into three decades of biological textbooks and Sunday-newspaper popularizations. The final third offers us the author's alternative vision. The targets for his criticism are designated respectively Homo pugnax (the claim that human beings are innately violent and aggressive); Homo egoisticus (the claim that we are innately selfish); and Homo operans (the claim that we are innately greedy).

Behind the first title shelter the presociobiological generation of popethologists such as Lorenz and Ardrey (in contradistinction to the recent obituaries, Barnett has no hesitation in referring to Lorenz's youthful Nazi enthusiasms and more recent New Right leanings). The claim of selfishness, of course, refers to the DNA-centric view of the universe offered by sociobiology's 'modern synthesis', and provides Barnett with the context for a synoptic account of neodarwinian evolutionary theory. Greediness turns out to mask the skinnerian vision of human beings as driven exclusively by contingencies of reinforcement, of reward and punishment, as epitomized in the utopian/dystopian vision of Walden Two. There have been numerous critiques of these positions, of course. E. O. Wilson himself described the writings of Ardrey and Lorenz as "mere advocacy". The sociobiologists have been criticized on scientific, ideological and philosophical grounds (this last especially by Philip Kitcher in his book Vaulting Ambition, which oddly does not appear in Barnett's extensive bibliography). Chomsky's polemic with Skinner is well known.

Barnett, bringing to these debates a combination of deep familiarity with the ethological and anthropological literature and a gentle wit, has little difficulty in exposing the shallowness of each of the three visions of humanity. He leaves unaddressed, however, the question of just why these views have achieved the popular resonance, and their authors the fame, that they undoubtedly have. Just why should such poorly predicated and evidentially weak ideas continue to be taken seriously? For some, the answer lies in the part they play in helping set political agendas; Barnett allows his readers to pose and answer such questions themselves. This reticence may be appropriate in a book which is evidently designed, as this one is, to serve as a teaching text in courses in the human sciences as well as for a wider audience.

It is to the last third of the book that one must turn to move beyond critique and to

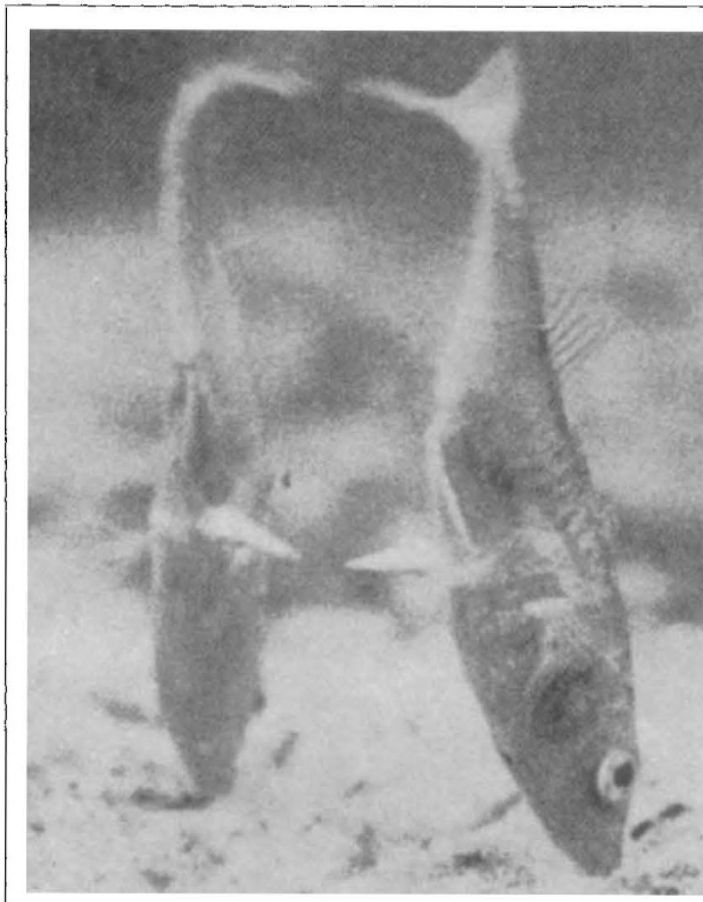

arrive at the author's own vision of human nature, the vision which informs the book's title. Reductionism and determinism fail as methods of understanding the human condition because in considerable measure our future is undetermined - we make our own history, though in circumstances not of our own choosing. Human beings are playful animals, curious animals, animals who make music, animals for whom work is not necessarily labour but can be liberating, unalienating. And human beings are also animals who teach. The reciprocal pleasures of teaching and learning, of the relationships between adults and children, are beautifully conveyed, both in prose and in many of the photographs which enliven the book.

Barnett's message is unfashionably optimistic. Certainly science and technology are associated with great horrors and with the peculiarly distorted visions which the first portion of the book is concerned to dispose of. Equally certainly, human perfectibility is not an option. When television screens are full of images of war and starvation, when fanatical fundamentalists can condemn to death a writer who dares to laugh, it is hard to hold on to a utopian perspective. But Barnett remains unshakeably a progressive. We do our present age an injustice, he argues, if we cling to ideas of human beings as greedy, violent and selfish, and fail to realize not only how far we have to go, but also how far we have already travelled towards a free, egalitarian and democratic society, a society which it is in accord with our biological natures to create.

Steven Rose is Director of the Brain and Behaviour Research Unit, The Open University, Milton Keynes MK7 6AA, UK.

Threatening gesture - the male three-spined stickleback Gasterosteus aculeatus in a posture that intimidates other males of the same species, here seen intimidating its own reflection. The behaviour is innate, and depends on both internal motivation and externa! sensory factors. The picture is taken from a reprint of The Study of Instinct by Nikolaas Tinbergen, who died last year (see SA Barnett's obituary in Nature 337 , $509 ; 1989)$. The book contains the original text written in 1949 , along with an introduction added in 1969 and a brief 1988 preface. Publisher is Clarendon, price is $£ 12.95$. 